\title{
O situaciji. Od „post” prema „proto”
}

Članak je zadržan u integralnom obliku i odstupa od standardnog načina citiranja i navođenja izvora koji se primjenjuje u [sic]-u.

Među pojmovima i terminima koji određuju kulturnu samosvijest i kretanje humanističkih znanosti na kraju 20. stoljeća prvo mjesto ne pripada imenici ili pridjevu, već prefiksu „post-”. Postmodernizam, poststrukturalizam, posthistorizam, postutopizam, postkolonijalizam, postkomunizam i mnoštvo drugih post-ova lijepilo se uz razne pojave, s ciljem da što prije padnu u zaborav. Magija prefiksa „post-” u tome je što omogućuje da se pozdravimo i bacimo u ropotarnicu prošlosti sve što je do jučer bilo suvremeno i aktualno. Bilo bi jednostavnije raskrstiti s urbanizmom ili lirizmom, kršćanstvom ili liberalizmom kada bi se na njih prilijepila etiketa „post-” i kada bi se nova, progresivna pozicija predstavila kao posturbanizam, postlirizam, postkršćanstvo, postliberalizam...

Međutim, takav način renovacije stvara plodno tlo za pravi poraz. „Post-”logika manjkava je jer je uvjetovana onim istim pojmovima koje pokušava ostaviti u prošlosti, ona vuče za sobom njihov konceptualni rep. Primjerice, pojam „poststrukturalizam” čvrsto je prikovan za onaj isti strukturalizam od kojega se i pokušava ograditi. Ta je uvjetovanost prošlim još očitija u danas pomodnom umnožavanju prefiksa „post-”: primjerice, kucnuo je čas da se postmodernizam odbaci u prošlost odvažnim dodavanjem još jednog prefiksa „post-”: post-postmodernizam. Tako na jednoj akademskoj filozofskoj internetskoj stranici možemo naći sljedeće primjere „post-post-” diskursa: „Aktualna pitanja humanističkih znanosti usredotočena su na razdoblje posthistorije, postpostmodernosti, postumjetnosti, postkapitalizma, postfilozofije, post-poststrukturalizma, postroda, postrase, postmetanarativa: lista je beskonačna, kao i sama pitanja. ${ }^{\lceil 1]}$

Takvo mehaničko dodavanje prefiksa - post-postmodernost, post-poststrukturalizam - oslobađa od nužnosti kvalitetnog definiranja novosti te se beskonačnom autoreferencijalnošću pojam pretvara u samoparodiju. 
Međutim, na prijelazu iz 20. u 21. stoljeće pojavio se radikalan pomak u kulturnoj samospoznaji. Mi ne živimo poslije (modernizma, strukturalizma, utopizma, komunizma...), nego na samom početku novog razdoblja, koje bolje opisuje prefiks „proto-”: protoglobalni, protoinformacijski, protovirtualni... Primjerice, naša bi se civilizacija mogla nazvati protoglobalnom zato što globalnost pretpostavlja, u skladu s općeprihvaćenom znanstvenom definicijom koju je prvi istaknuo sovjetski astrofizičar N. S. Karadašev, ovladavanje svim izvorima energije određene planete te sposobnost upravljanja i mijenjanja njezine klime (civilizacija prvog tipa je „planetarna”). Prema procjenama stručnjaka, našoj će civilizaciji trebati još tri do četiri stoljeća kako bi doista postala globalnom. Promotrimo stavove istaknutih suvremenih znanstvenika, fizičara Stephena Hawkinga i biologa Edwarda Wilsona, koji su skloni opisivati naše vrijeme terminom „proto” umjesto „post”. Stephen Hawking u knjizi Svemir u orahovoj ljusci piše: „Ali sada se nalazimo na početku nove ere, u kojoj ćemo moći povisiti kompleksnost našeg unutarnjeg koda, DNK-a, bez čekanja sporog procesa biološke evolucije. ${ }^{\ddagger 2]} 2$ Iz toga proizlazi da se sadašnje stanje čovječanstva može okarakterizirati kao protobiotehničko. Edward Wilson u svojoj knjizi Pomirenje: jedinstvenost znanja navodi: „Predvidljive sinteze [različitih ogranaka znanosti], konačan cilj znanosti, još je u ranoj fazi, a posebice $u$ biologiji. ${ }^{[3]}$ Iz toga slijedi da bi se trenutačno stanje interdisciplinarne suradnje moglo nazvati protosintetskim.

Takve i slične „proto” kovanice sveprisutne su na prijelazu stoljeća. Porast moći računala svjedok je stvaranja umjetne protointeligencije; genetički eksperimenti, posebice kloniranje, nagovještaj su mogućnosti stvaranja umjetnog protoživota; globalna internetska mreža zametak je protoglobalne suradnje umova i kolektivnog protorazuma.

Zanimljivo je da se pojam „post” gotovo po navici često koristi za pojave koje bi prikladnije bilo označiti kao „proto”. N. Katherine Hayles u svojoj poznatoj i utjecajnoj knjizi Kako smo postali postljudi definira naše doba unutar pojma „post”: „Prije svega, perspektiva postljudskoga privilegira informativni obrazac u odnosu na njegov materijalni kontekst, stoga se naše utjelovljenje u biološkom supstratu više razmatra kao povijesna slučajnost, nego kao neizbježnost života. ${ }^{\lceil 4]}$ Međutim, slijedimo li logiku toga objašnjenja, sadašnje stanje civilizacije trebalo bi okarakterizirati prije kao „postinformativno” nego kao „postljudsko”. Ljudsko se tijelo sve češće proučava kao ustroj 
znakova, ukupan zbroj informativnih procesa koji se događaju na svim razinama organizma. Nobert Weiner svojevremeno je predvidio da će se u budućnosti čovjek moći prenijeti kao poruka, putem telegrafa[5] Drugi istaknuti teoretičar robotike i informatičke ere, Hans Moravec, smatra mogućim da se sadržaj ljudske svijesti spremi u memoriju računala ${ }^{[6]}$ Sve to ne govori o kraju čovjeka, već o početku preobrazbe njegovih materijalnih komponenti u informatičke.

Premda je cijela knjiga N. Katherine Hayles, počevši od naslova, prožeta „post-”konceptima, zanimljivo je da u zaključku „Što znači biti postčovjekom?” autorica zapravo propituje prikladnost te terminologije: „Ali postljudsko u konačnici ne označava kraj ljudskoga. Ono označava samo kraj određene koncepcije čovjeka... kao autonomnoga bića koje realizira svoju volju kroz individualno djelovanje i izbor. ${ }^{.7]}$

Bez obzira na to kako se odnosili prema takvoj radikalnoj pretpostavci, očito je da, u suštini, nije riječ o „postčovjeku”, nego o „protočovjeku”, o početku ekspanzije čovjeka izvan granica vlastita tijela, o perspektivi preobrazbe tijela u brojevnu os, informativnu bujicu: „U tom postljudskom modelu... funkcije se čovjeka šire zato što se šire parametri koji nastanjuju njegov kognitivni sustav. Nije riječ o tome da se napušta tijelo, da ga se ostavi iza sebe, već o tome da se utjelovljena svijest proširi na najrazličitijim specifičnim, lokalnim, materijalnim putevima, što bi bilo nemoguće postići bez elektroničkih proteza. ${ }^{[8]}$

Po shvaćanju Hayles, „postljudsko“ tako ne podrazumijeva uklanjanje ${ }^{[9]}$, već prije širenje ljudskoga, koje počinje izlaziti izvan okvira tjelesnosti kroz sustav elektronskih preinačivača, pojačivača, produljivača, koji tijelo pretvaraju u informacijsko polje koje nije zarobljeno unutar granica vremena i prostora. Očito je da se takva perspektiva odnosi i na svjetonazor „proto”, koji podrazumijeva otvorenost prema budućnosti, a ne završenost prošlosti.

Predodžba o simetričnosti „početka” i „kraja”, njihove međusobne korelacije, iskrivljuje asimetričnu prirodu vremena. Vrijeme je svojstvo nedovršivosti, superiornost početaka nad krajevima.

Pogledajmo, primjerice, književne žanrove. Tragedija, komedija, roman, esej - svi oni imaju više ili manje određene povijesne početke, no završetci tih žanrovskih tvorevina nisu vidljivi, skrivaju se iza horizonta. Sve što mi o tim žanrovima znamo tek su praslike njihove moguće budućnosti, 
„protožanrovi”. Tako shvaćen početak, koji vodi prema otvorenoj budućnosti, stvarajući mogućnost nastavka i nepredočivost završetaka, može se označiti kao „proto”.

M. M. Bahtin, koji je kategoriju nedovršivosti učvrstio u svijesti naših suvremenika, primijetio je sa žalošću: „Nama je u prvom planu gotovo i konačno. Mi i u antici izdvajamo gotovo i konačno, a ne ono embrionalno, ono što je u razvoju. Ne istražujemo evoluciju književnosti prije pojave pismenosti (u jeziku i obredu). ${ }^{[10]} \mathrm{U}$ drugom zapisu Bahtin suprotstavlja dva pristupa žanrovskoj problematici: „koji završava” i „koji započinje”, ili suvremenom terminologijom, „post” i „proto”. „Žanr, kao kompozicijski određenu (u suštini nepromjenjivu) cjelinu i žanrovsku evoluciju (tematsku i jezičnu) s još nerazvijenim tvrdim kompozicijskim kosturom možemo nazvati 'prafenomenom' žanrova. ${ }^{\lceil 11]}$

Bit nije samo u tome da se prouče prafenomeni već poznatih, izgrađenih žanrova, već i u tome da se prouči prafenomenalnost kao takva, u stadiju svoga oblikovanja, kada sudbina žanra još pripada budućnosti, točnije, jednoj od mogućnosti budućega.

Prefiks „proto”, kojim predlažem označiti redovit i nedovršen prijelaz u „post-postpostmodernističkoj" kulturi, radikalan je prijelaz od završnoga prema početnomu, kao prema načinu razmišljanja.

Thomas Kuhn uspoređuje smjenu znanstvenih paradigmi s trenutačnih preokretom viđenog u geštalt psihologiji, kada se isti crtež odjednom počinje percipirati posve drukčije. „Ono što se znanstveniku prije revolucije činilo da je patka, nakon revolucije se je ispostavilo da je zec. ${ }^{\text {¡12] }} \mathrm{Na}$ isti se način u suvremenim humanističkim znanostima mijenja i konceptualni obrazac: tamo gdje se je još nedavno vidio završetak „post”, odjednom se pojavljuje novi početak - „proto”. Sve što je prijašnja generacija podrazumijevala pod znakom „post” nova generacija vidi kao „proto”, kao pristup novom dobu, skicu novih kulturnih informacija.

Kraj stvarnosti o kojoj su toliko mnogo govorili „post-”mislioci, posebice J. Baudrillard... Za generaciju sredine 1990-ih, odnjegovanu u pelenama elektroničkih mreža, takozvani „kraj stvarnosti" samo je početak nove virtualne ere.

Kraj subjekta, smrt autora, brisanje potpisa - što su najavili Louis Althusser, Roland Barthes, 
Michel Foucault... Time se zapravo nije proglasio kraj, već početak nove epohe umnažanja autorskih ličnosti i konceptualnih karaktera ${ }^{[13]}$

Smrt utopije, koju su proglasili J. F. Lyotard i J. Baudrillard...

U devedesetima utopija ne uskrsava kao društveni projekt usmjeren na preoblikovanje svijeta, već kao novi intenzitet iskustva, širi horizont spoznaje koja se ne želi zatvoriti u igri s prošlošću ili „vječnom sadašnjošću”, već traži radikalno drukčiju budućnost.

Evo dvije primjedbe umjetnika i teoretičara, za koje utopija više nije mrtva, nego predstavlja novu priliku za oživljavanje umjetnosti i ličnosti. Francuski umjetnik Christian Boltansky: „Moja se je generacija odrekla utopije, ali bez utopije nema umjetnosti. Svaka utopija je opasna, ali ipak dopuštena; umjetnik će si dopustiti da bude prevaren, da ostane idiot, samo da ga vjera ne ostavi. Uvjeren sam da su kvaliteta umjetničkoga djela i utopija izravno povezani. ${ }^{[14]}$ Moskovski povjesničar umjetnosti Viktor Miziano: „Iznimno je važno sada aktualizirati i problem univerzalnog. Razumijem da je to utopija. To se događa posve svjesno, da, utopija je završena, živjela utopija. Utopija pojedincu daje puno važniji, širi horizont. ${ }^{[15]}$

Od 1970-ih su godina humanističke znanosti izrekle smrtnu kaznu kulturi, kao da je održano zasjedanje vojnoga suda: smrt metafizike, smrt autora, smrt povijesti, smrt utopije, smrt originalnosti, smrt istine, smrt čovjeka... i posljedično, smrt samih humanističkih znanosti, humanističkih pristupa i vrijednosti. Sada postaje sve jasnije da je sokratovska umjetnost akušerstva, ispomoći pri rođenju novoga, dostojniji zadatak za humanističke znanosti. Bahtinovska „embrionika”, „začinjalački” pristup žanrovima i kulturnim formacijama u nastajanju važan su ruski doprinos toj sokratskoj tradiciji.

Moguć je sljedeći opravdan prigovor protiv „proto” kao nove kulturne paradigme: ne proizlaze li odatle zaključci u duhu determinizma i teleologije? Obilježavajući određenu suvremenu tendenciju kao „proto-X”, podrazumijevam li ja time da je „iksizacija” u budućnosti neizbježna?

Po mom mišljenju, taj „proto” ne sadrži nikakve fatalističke premise. Ranije se određenje „proto” davalo onomu što je prethodilo već ranije poznatom. Tek kada se je renesansa činila dovršenom, kada je otišla u daleku prošlost (19. stoljeće), oznakom i početnom fazom imenovana je protorenesansa, koja joj je prethodila. Po analogiji i antičke i srednjovjekovne su ljubavne priče 
dobile naziv „protoromani”, dakle nakon što su i sam žanr romana i njegova teorija već bili oblikovani. Tako se iz već gotove, ostvarene budućnosti preimenovala prošlost, koja je tako djelovala kao stepenica koja je vodila do unaprijed zadanoga cilja. To je stupica determinizma, koji prošlost određuje njegovom vlastitom budućnošću, no stvarajući iluziju da prošlost sama predodređuje budućnost.

Međutim, pojam „proto” oštro mijenja svoj smisao kada se primijeni na suvremene pojave: on ne ukazuje na neminovnost, već na jednu od mogućnosti budućnosti. Ne možemo sa sigurnošću znati je li nešto protofenomen ili nije u trenutku njegova nastanka - sve što nam preostaje nagađanja su i nada. „Proto-X” znači ono što ima sklonost da postane $X$, da se razvije u smjeru X. Za razliku od međunarodnog prefiksa „pre-” ili ruskog „pred-” („predglobalni”), „proto-” u našem shvaćanju ne ukazuje na redoslijed u vremenu, nego na otvorenu priliku, zametnu fazu fenomena. To nije znak vremenskoga slijeda nego prije potencijalnosti, hipotetičnosti, konjunktiva.

Znak „proto” dopušta kulturi sve što je postmodernizam zabranio: novost, povijest, metafizika, čak i utopija. No oni su uskraćeni za one totalitarne pretenzije koje su ranije poticale da sumnjamo na intelektualne kasarne u njima, na master thinking. „Proto” je nov, nenasilan stav prema budućnosti u modusu „može biti” umjesto ranijeg „mora biti” i „neka bude”.

Izvor: Ėpštejn, Mikhail. 2004. Znak_probela. (O buduščem gumanitarnyh nauk). Novoe literaturnoe obozrenie, 2004, str. 23-32.

Prevele: Matea Krnić i Ema Marača 
[1] http://www.um.edu.mt/news/philosophysoc.html. Poznati politolog i povjesničar suvremenosti Samuel Huntington takav je svjetonazor, koji svemu najavljuje kraj, nadjenuo naziv „krajologija” (engl. endism, rus. koncevizm). Kao primjer naveo je poznatu ideju Francisa Fukuyame o „kraju povijesti", koja je svjetlo dana ugledala krajem 1980-ih. No ako nas je povijest koja je uslijedila ičemu naučila, tada je to neizbježnost krajologije same (v. Huntington, Samuel P. 1989. No Exit: The Errors of Endism, „The National Interest“, rujan).

[2] Hawking, Stephen. 2001. The Universe in a Nutshell. New York et al.: A Bantam Bookp. Str. 165.

[3] Wilson, Edward. 2010. Pomirenje: jedinstvenost znanja. Algoritam. Zagreb.

[4] Hayles N. Katherine. 1999. How We Became Posthuman: Virtual Bodies in Cybernetics, Literature and Informatics. Chicago; London: The University of Chicago Press. Str. 2.

[5] Wiener Nobert. 1954. The Human Use of Human Beings: Cybernetics and Society, 2d ed. Garden City, N. Y.: Doubleday. Str. 103-104.

[6] Moravec Hans. 1988. Mind Children: The Future od Robot and Human Intelligence. Cambridge: Harvard University Press. Str. 109-110.

[7] Hayles N. Katherine. Op. cit. Str. 286.

[8] Ibid. Str. 290-291.

[9] U originalu M. Ėpštejn koristi rusku riječ ustranenie, što je sigurna aluzija na ostranenie, pojam kojim je V. Šklovskij označio bit umjetnosti i definirao umjetnost kao postupak. Na hrvatski je jezik ta riječ prevedena kao očuđenje. Ovom smo prilikom odlučili da Ėpštejnovu riječi ustranenie prevedemo u značenjski prepoznatljivijem obliku, pri čemu se izgubila aluzija na formalistički književno-teorijski pojam (op. prev.).

[10] Bahtin M. M. 2002. Rabočie zapisi 60-ih - načala 70-ih gg. T. 6. U: Bahtin, M. M. Sobranie sočinenij. V 6 t. Moskva: Russkie slovari. Jazyki slavjanskoj kul'tury. Str. 398.

[11] Bahtin M. M. 1986. Literaturno-kritičeskie stat'i. Moskva: Hudožestvennaja literatura. Str. 513.

[12] Kuhn, Thomas. 2002. Struktura naučnyh revoljucij. Moskva: Ast. Str. 151. 
[13] Detaljnije o prijelazu od „post” prema „proto” vidi treći odlomak šestog poglavlja Debut de siècle. Manifest proteizma.

[14] Intervju s umjetnikom Christianom Boltanskim. „Novoe literaturnoe obozrenie”, 2, 1993.

[15] Kto est' kto v sovremennom iskusstve Moskvy. 1993. Moskva: Album. (bez paginacije).

\section{(c) (i) (9)}

Creative Commons Attribution-NonCommercial-NoDerivatives 4.0 International License 